become more tenuous as we understand more about how they function. Note that the first orientation-independent promoter element was found when a restriction fragment upstream of the sea-urchin $\mathrm{H} 2 \mathrm{~A}$ histone gene was inverted ${ }^{26}$.

We thank John Shepherd for carrying out the computer searches and for comments on the manuscript. We also thank Tom Bickle, Roman Klemenz, Peter Nielsen, Rolf Zeller, Denice Smith, Christopher Wright, Andreas Fritz and Thomas Bürglin for helpful comments and Christel Riedel for typing the manuscript. This work was supported by a grant from the Swiss National Science Foundation.

Note added in proof: Recent experiments carried out in collaboration with Angelo Tognoni and Walter Schaffner have shown that in CV1 (Monkey) cells the Xenopus U2 distal sequence element can functionally replace the SV40 enhancer to allow replication and T-antigen expression in SV40 mutants lacking the SV40 enhancer.

Received 6 February: accepted 16 May 1985

Banerji, J., Rusconi, S. \& Schaffiner, W. Cell 27, 299-308 (1981)

2. Moreau, P., Hen, R., Wasylyk, B., Everett, R., Gaub, M. P. \& Chambon, P. Nucleic Acids Res. 9, 6047-6068 (1981).
3. Cereghini, S. et al. Cold Spring Harb. Symp. quant. Biol. 47, 935-944 (1982).

4. Banerji, J., Olson, L. \& Schaffner, W. Cell 33, 729-740 (1983)

. Gillies, S. D., Morrison, S. L., Oi, V. T. \& Tonegawa, S. Cell 33, 717-728 (1983)

6. Borrelli, E., Hen, R. \& Chambon, P. Nature 312, 608-612 (1984).

Wildemann, A. G., Sassone-Corsi, P., Grundström, T., Zenke, M. \& Chambon, P. EMBO J. 3, 3129-3133 (1984)

8. Ephrussi, A., Church, G. M., Tonegawa, S. \& Gilbert, W. Science 227, 134-140 (1985).

9. Ares, M. Jr, Mangin, M. \& Weiner, A. M. Molec. cell. Biol. (in the press)

10. Mattaj, I. W. \& Zeller, R. EMBO J. 2, 1883-1891 (1983)

11. Roop, D. R., Kristo, P., Stumph, W. E., Tsai, M. J. \& O'Malley, B. W. Cell 23,671-680 (1981) 12. Murphy, J. T., Burgess, R. R., Dahlberg, J. E. \& Lund, E. Cell 29, 265-274 (1982)

13. Zeller, R., Carri, M.-T., Mattaj, I. W. \& De Robertis, E. M. EMBO J. 3, 1075-1081 (1984).

14. Mattaj, I. W. Trends biochem. Sci. 9, $435-437$ (1984).

15. Skuzeski, J. et al. J. biol. Chem. 259, 8345-8353 (1984).

16. Westin, G., Lund, E., Murphy, J. T., Pettersson, U. \& Dahiberg, J. E. EMBO J. 3, 3295-3301 (1984).

17. Bogenhagen, D. F., Wormington, W. M. \& Brown, D. D. Cell 28, 413-421 (1982).

18. Brown, D. D. Cell 37, 359-365 (1984).

19. Reeder, R. H., Roan, J. G. \& Dunaway, M. Cell 35, 449-456.

20. Parslow, T. G., Blair, D. L., Murphy, W. J. \& Granner, D. K. Proc, naen. Acad. Sci. U.S.A 81, 2650-2654 (1984).

21. Falkner, F. G. \& Zachau, H. G. Nature 310, 71-74 (1984)

22. Gruss, P., Dhar, R. and Khoury, G. Proc. nain. Acad. Sci. U.S.A. 78, $943-947$ (1981).

23. Krol, A., Lund, E. Dahlberg, J. EMBO J. (in the press)

24. Ciliberto, G., Buckland, R., Cortese, R. \& Philipson, L. EMBO J. (in the press).

25. Labhart, P. \& Reeder, R. H. Cell 37, 285-289 (1984)

26. Grosschedl, R. \& Birnstiei, M. L. Proc. nain. Acad. Sci. U.S.A. 77, 7102-7106 (1980).

27. Tani, T., Watanabe-Nagasu, N., Okada, N. \& Oshima, Y. J. molec. Biol. 168, 579-584 (1983)

28. Messing, J. \& Vieira, J. Gene 19, 269-276 (1982)

29. Mattaj, I. W. \& De Robertis, E. M. Cell 40, 111-118 (1985).

D. Mattaj, I. W. et al. in The Oxford Surveys on Eukaryotic Genes (Oxford University Press, in the press)

\section{Amplification of inter-Alu extrachromosomal DNA during cellular ageing: retraction and explanation}

\author{
R. J. Shmookler Reis, C. K. Lumpkin Jr*, \\ J. R. McGill*, K. T. Riabowol \& S. Goldstein
}

University of Arkansas for Medical Sciences, Departments of Medicine \& Biochemistry, Division of Gerontology Research, and Veterans Administration Medical Center, Little Rock, Arkansas 72205, USA

We reported previously ${ }^{1,2}$ the age-dependent appearance of extrachromosomal circular DNA bands hybridizing to a human DNA fragment ('inter-Alu'), isolated from a genomic cluster of $A l u I$ repeats ${ }^{3}$. Such bands appeared or increased at late passage in four out of six human fibroblast strains (six out of nine cell expansions); moreover, all DNAs (9/9) obtained from peripheral lymphocytes of aged donors, but none $(0 / 8)$ from young donors, revealed a non-genomic inter- $A$ lu band at $=4.8$ kilobases $(\mathrm{kb})^{1,2}$. Subsequent data extended these numbers to $16 / 24$ aged donors compared with $0 / 18$ young donors ${ }^{4}$. These results were interpreted as evidence of age-dependent DNA rearrangement in normal human cells ${ }^{1,2}$. We now report that the 'extra' bands were of microbial origin, although clearly occurring in an age-dependent manner.

The hybridizations reported ${ }^{1,2,4}$ primarily used the entire interAlu-containing plasmid, $\mathrm{p} \lambda \mathrm{H} 15 \mathrm{~A}$, as ${ }^{32} \mathrm{P}$-DNA probe. Gelpurified insert DNA also hybridized to the extrachromosomal species, which was then believed to be an adequate control for plasmid contamination. Such hybridization, however, could still be due to residual traces of vector DNA, "invariably present in [insert] probes ... even after two cycles of electrophoretic purification" (ref. 5). Control hybridizations against many of the same

* Present addresses: Baylor College of Medicine, Department of Cell Biology, Houston, Texas 77030, USA (C.K.L.): University of Texas Health Sciences Center, Department of Anatomy, 7703 Floyd Curl Drive, San Antonio, Texas 78284, USA.(J.R.McG.)
DNA preparations, with a pCR1 fragment or pBR322 plasmid containing other inserts, revealed no extra bands. However, when we obtained the parental vector for inter-Alu, pACYC184, we observed hybridization of this probe to the age-dependent bands in both fibroblast and lymphocyte DNA samples, indicating that such bands must be due to low levels of microbial plasmid DNA $\left(\simeq 10^{-6}\right)$ in our human DNA samples. We discussed the dangers of microbial contamination ${ }^{1}$, but were misled by unwarranted confidence in the controls, the pervasive extent and polymorphic nature of the contamination, and its remarkable age dependence.

In attempting to account for our data, we have considered the possibility of deliberate contamination and regard it as extremely unlikely. Inadvertent operator contamination, however, is difficult to reconcile with the marked age bias observed, in particular for the multiple fibroblast DNA bands seen in many independent samples, prepared by six persons over a 2 -yr period. Biological contamination is more plausible in the light of recent reports of microbial plasmid DNA in biopsy and necropsy tissue samples and in body fluids ${ }^{5-7}$. Our preliminary evidence indicates that plasmid-homologous DNA can be detected in filter-sterilized serum and trypsin, two common reagents for cell culture. Thus, the correlation between culture age and plasmid bands may reflect cumulative exposure of fibroblasts to plasmid DNA.

We apologize for any inconvenience to other investigators resulting from this error. Our experience, along with other reports ${ }^{5,6,8}$, underscores the danger of systematic plasmid contamination of DNA samples, and the necessity for control hybridizations using the appropriate vector alone as probe.

Received 19 March; accepted 2 May 1985.

1. Shmookler Reis, R. J., Lumpkin, C. K. Jr, McGill, J. R., Riabowol, K. T. \& Goldstein, S. Nalure 301, 394-398 (1983).

2. Shmookler Reis, R. J., Lumpkin, C. K. Jr, McGill, J. R., Rjabowol, K. T. \& Goldstein, S Cold Spring Harb. Symp. quant. Biol. 47, 1135-1139 (1983).

3. Calabretta, B., Robberson, D. L., Barrera-Saldana, H. A., Lambrou, T. P. \& Saunders, G. D. Nature 296, 219-225 (1982).

4. Goldstein, S., Lumpkin, C. K. Jr, McGill, J. R., Riabowol, K. T. \& Shmookler Reis, R. J. Clin. Res. 31, 478A, abstr. (1983).

5. Barbacid, M. Science 225, 670 (1984)

6. Hino, O., Kitagawa, T. \& Sugano, H. Science 225, 670-671 (1984).

7. Holmberg, S. D., Osterholm, M. T., Senger, K. A. \& Cohen, M. L. New Engl. J. Med. 311, 617-622 (1984)

8. Muschel, R. J., Khoury, G., Lebowitz, P., Koler, R. \& Dhar, R. Science 219, 853 (1983). 